\title{
Alkoholos májbetegség: a genetikai-epigenetikai tényezők szerepe és az absztinencia hatása
}

\author{
Pár Alajos dr. - Pár Gabriella dr. \\ Pécsi Tudományegyetem, Általános Orvostudományi Kar, Klinikai Központ, I. Belgyógyászati Klinika, Pécs
}

\begin{abstract}
Az alkoholos májbetegség patogenezise nemcsak az etanol toxikus hatásától, hanem a gazdaszervezet és a környezeti tényezők kölcsönhatásától is függ. A genetikai prediszpozíció mellett a komorbiditás és számos egyéb körülmény is szerepet kap a betegségkimenetel alakulásában. Másrészt a terápiás stratégiában meghatározó az etiológiai ágens kiiktatása, ez az alkohol esetén az absztinencia. A dolgozat áttekintést ad az alkoholos májbetegség genetikájáról, kockázati tényezőirôl és az absztinencia hatásáról. Az alkohol metabolizmusában szerepet játszó alkohol-dehidrogenáz $\mathrm{ADH} 1 \mathrm{~B}$ *2 és aldehid-dehidrogenáz ALDH2 2 variánsai „védő hatásúak” az alkoholizmussal szemben, az általuk okozott magas véracetaldehid-szinttel kapcsolatos panaszok miatt. A citokróm P450 CYP2E1 * 5 c2 indukálható mikroszomális oxidáz, alkoholhatásra jelentősen megnőtt aktivitása acetaldehid és reaktívoxigén-gyökök fokozott képzése révén súlyosbítja a májkárosodást. Három új génpolimorfizmus - a patatin-like phospholipase domain-containing 3 (PNPLA3 I148M C>G), a transmembrane 6 superfamily member 2 (TM6SF2 E167K) és a membranebound O-acyltransferase domain-containing 7 (MB0AT7 rs641738 C>T) - a steatohepatitis, a fibrosis és a hepatocellularis carcinoma kockázati tényezőjének bizonyult mind alkoholos, mind nem alkoholos zsírmájas és cirrhosisos betegekben. Az alkohol által kiváltott epigenetikai hatások, a reverzibilis, de örökölhető génexpresszió-változások mint a hisztonmódosulások, a DNS-metilációk és a mikro-RNS-ek - azon túlmenően, hogy jelentősek a májbetegség keletkezésében, a jövőben diagnosztikus eszközként, illetve terápiás célpontként is szolgálhatnak. A nők háromszor érzékenyebbek az alkohol toxikus hatására, mint a férfiak, továbbá a malnutritio, az obesitas, a diabetes, a hepatitisvírus-infekció és a dohányzás is megnöveli a májbetegség kockázatát. Ugyanakkor az alkoholos májbetegséget megelőzhető betegségnek kell tekinteni. Számos klinikai megfigyelés utalt arra, hogy az alkohol tartós megvonása a steatohepatitis és a fibrosis regressziójához, a cirrhosis kompenzálódásához vezethet, a betegek állapotának javulásával és a túlélés megnövekedésével, még előrehaladott stádiumban is. Korai diagnózisra és az absztinencia fenntartásához multidiszciplináris intervencióra van szükség, hogy az alkoholos cirrhosis megelőzhető legyen.
\end{abstract}

Orv Hetil. 2019; 160(14): 524-532.

Kulcsszavak: alkohol, májbetegség, genetika, epigenetika, absztinencia

\section{Alcoholic liver disease: the roles of genetic-epigenetic factors and the effect of abstinence}

The pathogenesis of alcoholic liver disease depends not only on the toxic effects of alcohol, but also on the complex interaction of host's and environmental factors. Thus, the genetic pre-disposition, co-morbidities and behavioral factors all play a role in the individual variations in the disease outcomes. On the other hand, the essential part of the therapeutic strategy is the complete withdrawal of the harmful etiological agent. The present paper is devoted to overview the genetics, the environmental factors and the effects of abstinence in alcoholic liver disease. Genetic variants in two enzymes involved in the metabolism of ethanol, alcohol-dehydrogenase ADH1B 2 and aldehyde-dehydrogenase ALDH2 2 through increasing the blood level of acetaldehyde, may play a "protective" role against alcoholism. The P450 CYP2El $5 \mathrm{c} 2$, an inducible microsomal oxidase, upregulated by ethanol and by formation of acetaldehyde and reactive oxygen species, increases liver toxicity. Three novel gene polymorphisms - such as the patatin-like phospholipase domain-containing 3 (PNPLA3 I148M C>G), the transmembrane 6 superfamily member 2 (TM6SF2 E167K), and the membrane-bound O-acyltransferase domain-containing 7 (MB0AT7 rs641738 C>T) have been proven as risk factors of steatosis, fibrosis and even hepatocellular carcinoma in both alcoholic and nonalcoholic fatty liver disease patients. Alcohol-induced epigenetic effects, reversible but inheritable gene expression alterations - as histon modulations, DNA methylation and micro-RNA-s - are of importance in the pathogenesis as well, and in the future, they may serve as diagnostic markers and therapeutic targets. Women are at greater risk of developing alcoholic cirrhosis, furthermore, malnutrition, obesity, diabetes, smoking, and hepatitis virus infections 
are also risk factors. Alcoholic liver disease should be regarded as a preventable disease. Several clinical studies revealed that abstinence may result in the regression of steatohepatitis and fibrosis, compensation of cirrhosis, improving disease outcome and increasing survival even in patients with advanced stages. Early diagnosis and multidisciplinary interventions are highly required to achieve long-term abstinence and to prevent alcoholic cirrhosis.

Keywords: alcohol, liver disease, genetics, epigenetics, abstinence

Pár A, Pár G. [Alcoholic liver disease: the roles of genetic-epigenetic factors and the effect of abstinence]. Orv Hetil. 2019; 160(14): 524-532.

(Beérkezett: 2018. november 7.; elfogadva: 2018. november 21.)

\section{A Szerkesztôség felkérésére készült tanulmány}

\section{Rövidítések}

$\mathrm{AA}=$ acetaldehid $; \mathrm{ADH}=($ alcohol dehydrogenase $)$ alkoholdehidrogenáz; $\mathrm{AH}=$ (alcoholic hepatitis) alkoholos hepatitis; $\mathrm{ALDH}=$ aldehid-dehidrogenáz; $\mathrm{CD}=$ (cluster of differentiation) sejtfelszíni receptor és differenciációs marker; CYP = citokróm; DNS = dezoxiribonukleinsav; $\mathrm{ER}=$ endoplazmatikus reticulum; GWAS = (genom-wide association study) teljesgenom-társulási vizsgálat; $\mathrm{HBV}=$ hepatitis $\mathrm{B}$-vírus; $\mathrm{HCC}=$ hepatocellularis carcinoma; $\mathrm{HCV}=$ hepatitis $\mathrm{C}$-vírus; $\mathrm{HR}=$ (hazard ratio) kockázati arány; $\mathrm{IL}=$ interleukin; $\mathrm{LPS}=$ lipopoliszacharid; $\mathrm{M}=$ metionin; MBOAT7 = membrane-bound $\mathrm{O}$-acyltransferase domain-containing $7 ;$ MEOS $=$ (microsomal ethanol oxidizing system) mikroszomális etanoloxidáló rendszer; $\mathrm{miR}=$ mikro-RNS; NAFLD $=$ (non-alcoholic fatty liver disease) nem alkoholos zsírmájbetegség; $\mathrm{NASH}=($ non-alcoholic steatohepatitis) nem alkoholos steatohepatitis; OR = (odds ratio) esélyhányados; PAIl = plazminogénaktivátorinhibitor-1; PNPLA3 = patatin-like phospholipase domain-containing $3 ;$ RNS = ribonukleinsav; ROS = (reactive oxygen species $)$ reaktívoxigén-gyök; $\mathrm{RR}=$ (relative risk) relatív kockázat; SNP $=($ single nucleotide polymorphism $)$ egyszeres nukleotidpolimorfizmus; SOD = (superoxide dismutase) szuperoxid-dizmutáz; TG = triglicerid; TGF $\beta=$ (transforming growth factor beta) transzformáló növekedési faktor- $\beta$; TLR = (Toll-like receptor) Toll-szerû receptor; $\mathrm{TNF}=$ tumornekrózis-faktor; $\mathrm{TNF} \alpha=$ tumornekrózisfaktor- $\alpha$; TM6SF2 = transmembrane 6 superfamily member $2 ; \mathrm{VLDL}=$ (very low density lipoprotein $)$ nagyon alacsony sưrüségű lipoprotein

A túlzott alkoholfogyasztás világszerte nagy közegészségügyi probléma: felelős a globális mortalitás $5,9 \%$-áért, és évente legalább félmillióra tehető az alkoholos májbetegséggel kapcsolatos halálozás. Az alkohol okozta májkárosodás - hasonlóképp, mint a nem alkoholos zsírmájbetegség $[1,2]$ - spektruma a steatosistól a steatohepatitisen és a cirrhosison át a hepatocellularis carcinomáig (HCC) terjed, és a második leggyakoribb oka a májtranszplantációnak [3].

$\mathrm{Az}$ alkoholos májbetegség úgynevezett kompex betegség: genetikai és környezeti tényezők kölcsönhatása határozza meg súlyosságát és kimenetelét. Ebben az etiológiai faktor, az alkohol döntő szerepet játszik, azonban a tény, hogy a nagyivóknak csak 15-20\%-a lesz cirrhosisos, jelzi, hogy az említett egyéb körülmények hatásával is számolni kell. Másrészt az alkoholos májbetegség megelózésének és gyógyításának alapvető feltétele a kórok kiküszöbölése, ami pedig a tartós absztinenciát jelenti $[4,5]$.

Dolgozatunkban az alkoholos májbetegségben jelentős szerepet játszó genetikai, epigenetikai és környezeti tényezóket, valamint az absztinencia hatását tárgyaljuk. A kórkép patogenezisével és klinikumával a közelmúltban több külföldi [4-7] és két hazai összefoglaló közlemény $[8,9]$ is foglalkozott.

\section{Genetikai faktorok}

Epidemiológiai és családtanulmányok már korábban felvetették az alkoholos cirrhosis örökletes vonását, és ezt támogatták a kandidátusgén-asszociációs vizsgálatok is. Az utóbbi évtizedben pedig a teljesgenom-társulási vizsgálatok (genome-wide association studies, GWAS) és a metaanalízisek hoztak további új eredményeket e téren $[4,5,10-13]$.

\section{Családvizsgálatok}

Alkoholos májbetegségben a genetika szerepére utaltak azok az első ikervizsgálatok, amelyek szerint 15924 alkoholos cirrhosisos férfi ikerpár esetén a cirrhosis konkordanciája 3 -szoros (14,6/1000 versus 5,4/1000) volt a monozigótákban a kétpetéjú ikrekhez képest [14]. Később az Egyesült Államokban a hispán népességben gyakrabban és 10 évvel korábban észlelték az alkoholos cirrhosist, mint az afroamerikaiakban és a kaukázusiakban, bár ebben a genetikai faktorokon kívül a kulturális, szociális különbségeknek és a fogyasztott alkohol típusának is szerepe lehet $[10,15]$. Alkoholos cirrhosisos betegek gyakran számoltak be arról, hogy apjuk májbetegségben halt meg. A családvizsgálatok metaanalízisei alapján az alkoholos cirrhosis 21-67\%-ban örökletes betegség [1012].

Az alkoholdependenciára és a májbetegségre való fogékonyságot meghatározó genetikai tényezők különböznek és függetlenek egymástól. (Az alkoholdependenciára jellemző az alkohol neurobiológiai hatásaival szembeni 
tolerancia, a megvonási szindróma, az alkohol iránti „sóvárgás" és a kontroll nélküli alkoholfogyasztás a várható következmények ismerete ellenére) $[4,5,10]$. Az alkoholfüggőség örökletességét ikervizsgálatok alapján is állították. Azt is leírták, hogy alkoholista egyén férfi testvérének 49,7\%-os, nőnek 22,4\%-os az esélye, hogy élete folyamán dependenssé váljon, illetve a szülők alkoholizmusa esetén 3-4-szeres a kockázat a leszármazott alkoholfüggőségére. Metaanalízisek szerint az alkoholdependencia 24-49\%-ban (férfiakban 30-36\%-ban) örökletes betegségnek tekinthető $[5,10,12,16]$.

\section{Kandidátusgén-vizsgálatok}

Olyan génpolimorfizmusokat elemeztek, amelyekről korábbról tudott volt, hogy bizonyos betegségek patofiziológiájában szerepet játszanak, így például funkcionális proteineket kódolnak, mint endotoxinreceptorok, citokinek, az oxidatív stressz, a lipidmetabolizmus vagy az immunreguláció mediátorai. A kandidátusgén-vizsgálatok a priori hipotézisen alapulnak: a génvariánsok közül kiválasztanak egyeseket, amelyekról feltételezik, hogy relevánsak lehetnek, például az alkoholos májbetegség kialakulásában $[5,10,16]$.

$\mathrm{Az}$ alkoholmetabolizáló enzimek egyes polimorfizmusairól az elsők között lett ismert, hogy változást okoznak az enzimkinetikában, az acetaldehid (AA) képzésében, illetve eliminációjában, és befolyásolják egyrészt a hepatotoxicitást, másrészt az alkoholizmusra való hajlamot. Ezek a variánsok különösen a kelet-ázsiai populációkban gyakoriak [5, 10-12, 15].

Az alkohol-dehidrogenáz $(\mathrm{ADH})$ a májsejtek citoplazmájában felelős az alkohol oxidatív metabolizmusának 80\%-áért alacsony fokú expozíció esetén. Nőkben a gyomormucosa ADH-aktivitása alacsony, ami az alkohol fokozott felszívódásához vezet $[10,17]$. Az enzim ADH1B * rs1229984-es variánsa magas aktivitású, fokozott AAképzéssel és hepatotoxicitással jár. Európában a populáció 19\%-ában fordul elő, Kelet-Ázsiában a népesség 1991\%-ában. Az alkoholizmussal szembeni „védo”” hatása a magas vér-AA-szint okozta panaszok miatt kialakuló averzióval kapcsolatos [18] (1/A ábra).

$\mathrm{Az}$ aldehid-dehidrogenáz ALDH2 2 rs671-es variánsa csökkent enzimaktivitású, ezáltal okozza az AA felhalmozódását. Kelet-Ázsiában a népesség 30-50\%-ában fordul elő, az alkoholizmus ellen "védő" hatású (RR: 0,25), cirrhosisban ritka [19] ( $1 / B$ ábra).

A citokróm P450 CYP2El a mikroszomális etanoloxidáló enzimrendszerhez (MEOS) tartozik. Indukálható enzim, krónikus alkoholhatásra aktivitása 10-20-szorosra fokozódik, és megnő az AA és a reaktívoxigén-gyökök (ROS) képzése. A CYP2E1 5 c2-es variáns magas aktivitású enzim, gyakori cirrhosisban $[10,12]$ (1/C ábra) [10].

A CYP2El cl-es allél és az ADHIC *1-homozigóta együttes előfordulása a HCC magas kockázatával jár alkoholos májbetegekben $[10,12]$.
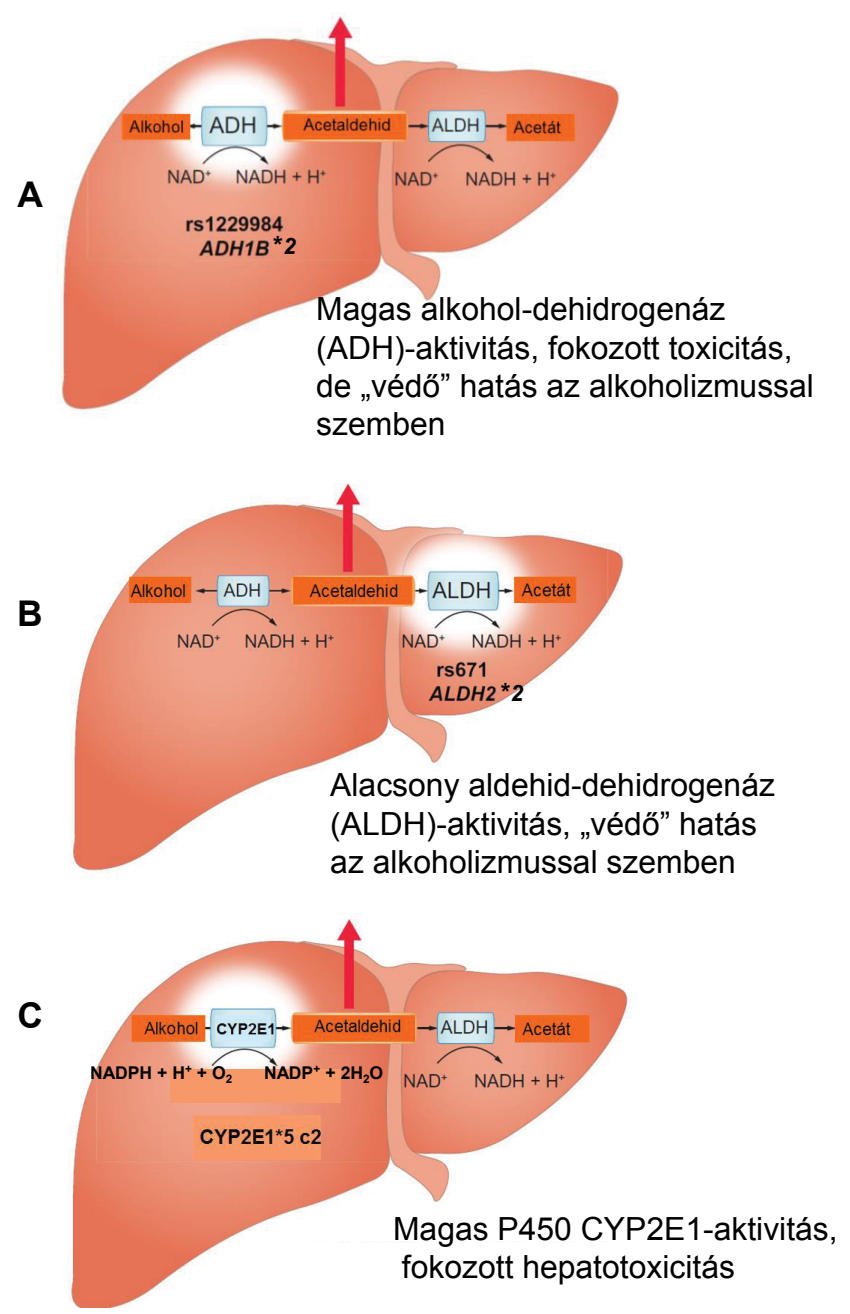

1. ábra $\quad$ Az alkohol-dehidrogenáz (A), az aldehid-dehidrogenáz (B) és a P450 CYP2E1 (C) magas acetaldehidszintet okozó variánsai [10]

$\mathrm{ADH}=$ alkohol-dehidrogenáz; ALDH = aldehid-dehidrogenáz; $\mathrm{NAD}=$ nikotinamid-adenin-dinukleotid; $\mathrm{NADH}=\mathrm{NAD}$-hidrid; NADPH = NAD-foszfát

A SOD2 (szuperoxid-dizmutáz) védő hatású az oxidatív stresszel szemben. A SOD2-gén rs4880 Al6V variánsa esetén a minor T-allél a SOD2-funkció kiesésével, ROS elleni csökkent védelemmel jár [10, 12].

A CD14 a lipopoliszacharid (LPS)-receptorkomplex alkotója, a CDl4-gén promóter régiójában a -159 C>T variáns esetén a $\mathrm{T} / \mathrm{T}$ genotípus magas szolúbilis és membránkötött CDl4-expresszióval jár, és fibrosisra hajlamosít $[10,12]$.

$\mathrm{Az}$ interleukin-10 (IL10)-gén promóterében -627 $\mathrm{C}<\mathrm{A}$ variáns esetén az A-allél csökkent IL10-aktivitást és fokozott gyulladásos választ okoz, hispánokban gyakori $[10,12]$.

A tumornekrózisfaktor (TNF)-gén rs361525-ös (G238A) variánsa ritka egészségesekben, de gyakrabban fordul elő alkoholos májbetegekben, mint a nem májbeteg nagyivókban. A cirrhosissal való szoros kapcsolatát nem lehetett igazolni $[10,13,20]$. 


\section{Teljesgenom-társulási vizsgálatok (genom-wide association studies, GWAS)}

Egyidejüleg több millió, egy nukleotidot érintő polimorfizmust (SNP) elemeznek: „nullhipotézisen” alapuló vizsgálatok, általuk olyan génvariánsok azonosíthatók, amelyekról korábban nem volt ismert betegséggel való kapcsolatuk. GWAS-kal az utolsó évtizedben három olyan SNP-t fedeztek fel, amelyek patogenetikai szerepet játszanak nem alkoholos zsírmájbetegségben (NAFLD) és alkoholos májkárosodásban is.

A PNPLA3 (patatin-like phospholipase domain-containing 3) 22-es kromoszómán (22q13.13) lokalizált génje triacil-glicerol-lipázt (adiponutrint), egy 481 aminosavból álló transzmembrán polipeptidet, triglicerid-hidrolázt kódol. Az enzim a májsejtekben, a lipidcseppek felszínén, az endoplazmatikus reticulum (ER) membránjain, az adipocytákban és a hepaticus őssejtben lipáz aktivitású, és részt vesz a retinol metabolizmusában [21].

A PNPLA3 rs738409-es variánsa kockázati tényezőnek bizonyult először nem alkoholos steatohepatitisben (NASH) [18], majd alkoholos májbetegségben is [22]. Az SNP esetén a proteinben az izoleucint (I) metionin (M) helyettesíti (I148M), ami a foszfolipázfunkció kiesésével jár. Az enzimkonfiguráció változása miatt a szubsztrát triglicerid nem fér hozzá az aktív helyhez. A trigliceridek csökkent hidrolízise, a lipoproteinek (VLDL) májból történő csökkent szekréciója, a retinol retenciója és fokozott retinoltoxicitás a következmény.
Az Il48M GG genotípus a májban kétszeres trigliceridtartalommal jár, megnő a májbetegségre való hajlam, fokozott lobularis infiltráció és ballonsejtképződés, gyorsabb fibrosisprogresszió és a HCC nagyobb kockázata volt észlelhető [22-24] (2. ábra) [13].

Alkoholos májbetegségben Il48M CG heterozigótákban (G-allél-hordozókban) 2,1-szeres, a G/G homozigótákban 3,37-szeres a cirrhosis kockázata; cirrhosisban a G-allél kétszeres, a G/G genotípus négy-ötszörös HCC-kockázattal jár. A PNPLA3 I148M előfordulása kelet-ázsiai és mexikói populációkban gyakori; a betegek fiatalabbak, cirrhosisuk rövidebb idő alatt dekompenzálódik [22-25].

Atkinson és mtsai vizsgálatában súlyos alkoholos hepatitisben (AH) az I148M G-allél a betegek 29,5\%-ában, a nem májbeteg nagyivókban 18,9\%-ban fordult elő. A 90 napot túlélő $\mathrm{AH}$-betegek halálozása $\mathrm{G} / \mathrm{G}$ genotípus esetén $34,7 \%, \mathrm{C} / \mathrm{C}$ genotípusban $25,1 \%$ volt (HR: 2,7). A $\mathrm{G} / \mathrm{G}$ genotípus még absztinensekben is magas $(36,4 \%)$ halálozással járt, ez C/C genotípusban $12 \%$ volt. Az adatok alapján a PNPLA3 SNP-vizsgálata támpontot nyújt az AH prognózisára, segítheti a betegkiválasztást a korai transzplantáció indikálásához [26].

Stickel és mtsai szerint a PNPLA3 I148M az első olyan genetikai marker, amely valóban prediktora az alkoholos májbetegség súlyosságának [10].

A TM6SF2 (transmembrane 6 superfamily member 2) 19-es kromoszómán lokalizált génje (19.pl3.3-pl2) egy 377 aminosavat tartalmazó proteint kódol, amely az endoplazmatikus reticulum (ER) membránján a lipidtranszferben, a nagyon alacsony súrúségú lipoprotein

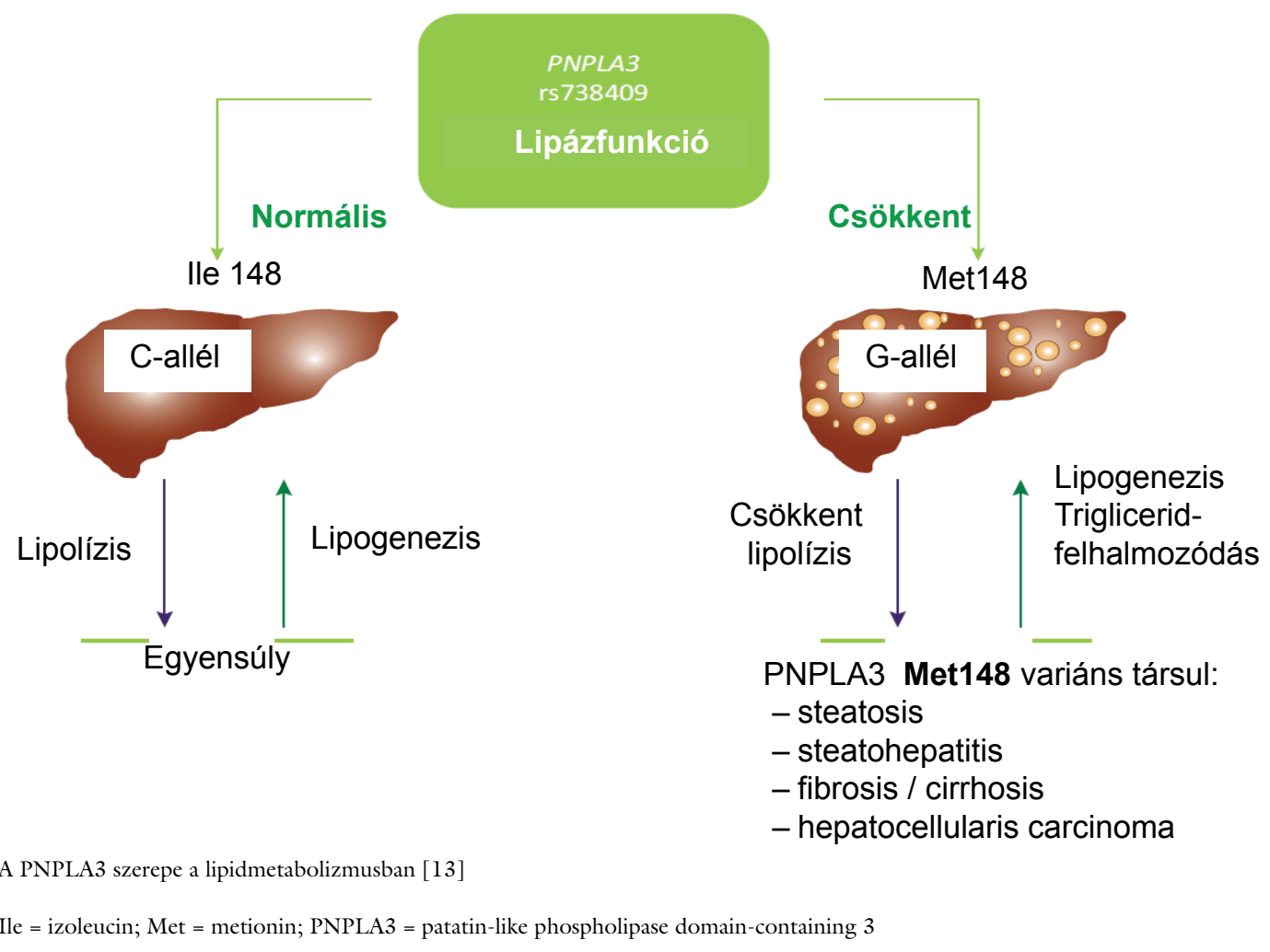


(VLDL) szekréciójában játszik szerepet. A TM6SF2 aktivitása a májból a vérbe fokozott trigliceridkiválasztáshoz és megnövekedett cardiovascularis kockázathoz vezet [27].

A TM6SF2-gén rs58542926-os variánsa (C>T) a génben lizin-glutamin cserével (E167K) jár. A minor T-allél esetén károsodik a májból a VLDL-szekréció, ami a vérben alacsony VLDL-szintet, a májban fokozott fibrosist okoz. Az alacsony VLDL-szint ugyanakkor védő hatású a cardiovascularis betegséggel szemben (3. ábra) [13]. A TM6SF2 T-alléljének hordozása alkoholistákban 1-1,9-szeres kockázatot jelent cirrhosisra [9-11, 27], továbbá a PNPLA3 G-genotípussal együtt megnöveli a HCC kockázatát is [28].

Falleti és mtsai - mivel alkoholos cirrhosisban a HCC kockázatát PNPL3 G/G genotípus esetén (OR: 2,85) és TM6SF2 T/T genotípus esetén (OR: 2,57) hasonlóan magasnak találták - felvetették, hogy kölcsönhatás állhat fenn a két génvariáns között [25].

A MBOAT7 (membrane-bound O-acyltransferase domain-containing 7) génje a 19-es kromoszómán lokalizált (13.q13.42), és a lizofoszfatidil-inozitol-aciltranszferázt kódolja. Az enzim a zsírsavaknak a foszfolipidek és a lizofoszfolipidek közötti átvitelét, a foszfolipidek reacetilációját katalizálja, az arachidonsav- és eikozanoidszintet szabályozza, gyulladásgátló hatású. A gén rs641738 C > T variánsa esetén a T-allél a gén csökkent expressziója növeli az arachidonsav elérhetőségét és a prosztaglandinképzést, emelkedett IL6-, ILl $\beta$ - és TNF $\alpha$-szintet, gyulladást okoz [10-12, 29]. A MBOAT7 T-allélje alkoholos májbetegségben a fibrosis fokozott kockázatával jár [13].
Az újonnan felfedezett génvariánsok megismerése további közvetlen bizonyitékokat szolgáltatott a genetikai tényezők jelentôségére az alkoholos májbetegség patogenezisében. Ugyanakkor ezek a genetikai markerek prognosztikai mutatóként szolgálhatnak egyrészt súlyos akut alkoholos hepatitisben a terápiát, másrészt cirrbosisban a HCC kockázatát illetôen.

\section{Epigenetikai módosulások}

Az alkoholos májbetegség kialakulásában fontos szerepet játszanak azok a szerzett, reverzibilis, de örökölhető génmódosulások is, amelyek a DNS-szekvenciát nem érintik, de befolyásolják a génexpressziót és a sejtfunkciókat. Ezeket az epigenetikai változásokat a gén és a környezet kölcsönhatásai okozzák, megnyilvánulásaik a különböző transzkripciós és poszttranszlációs módosulások, mint a DNS és hisztonproteinek acetilációja, metilációja, foszforilációja, a kromatinstruktúra elváltozásai vagy a jelátviteli utak aktiválása.

A génexpresszió módosulásai fenotípusváltozáshoz, például betegségre való hajlam fokozódásához is vezethetnek. A DNS és a hiszton módosulásai, illetve a mikroRNS-ek olyan mechanizmusok, amelyek ha tartósak, átvihetők az utódba: ez transzgenerációs hatást jelent [30-33]. Az epigenetikai változásokat xenobiotikumok is elindíthatják, ezek között az alkohol is kulcsfontosságúnak bizonyult (4. ábra) [30].

Az alkohol a biszton H3-as lizin acetilációját, valamint a szerin foszforilációját indukálhatja. A hisztonprotein $\mathrm{N}$-terminálisának acetilációja fokozódik, mivel az AA és az acetát révén megnő a rendelkezésre álló acetilcsoportok mennyisége. A ROS is fokozza a hisztonacetilációt.

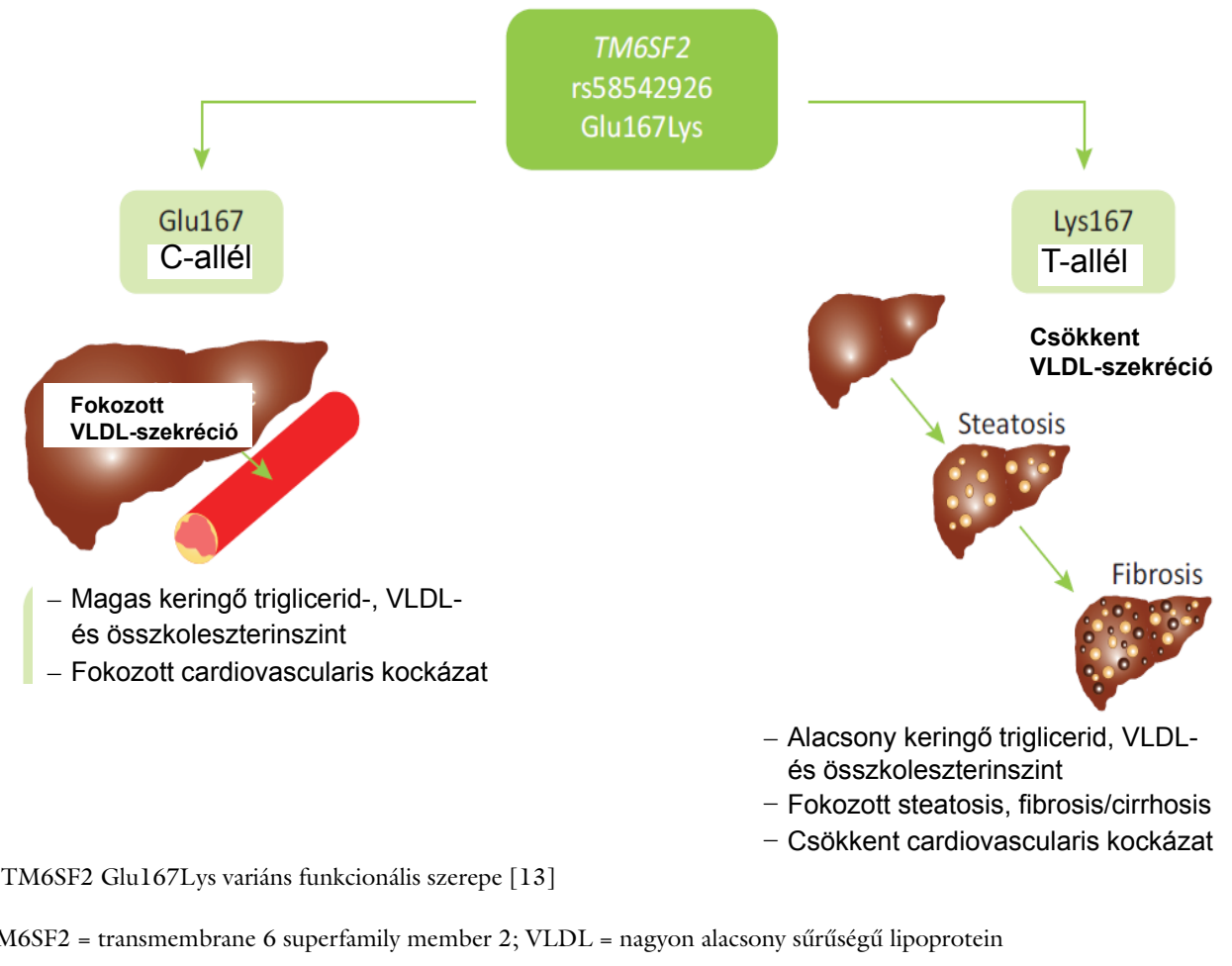




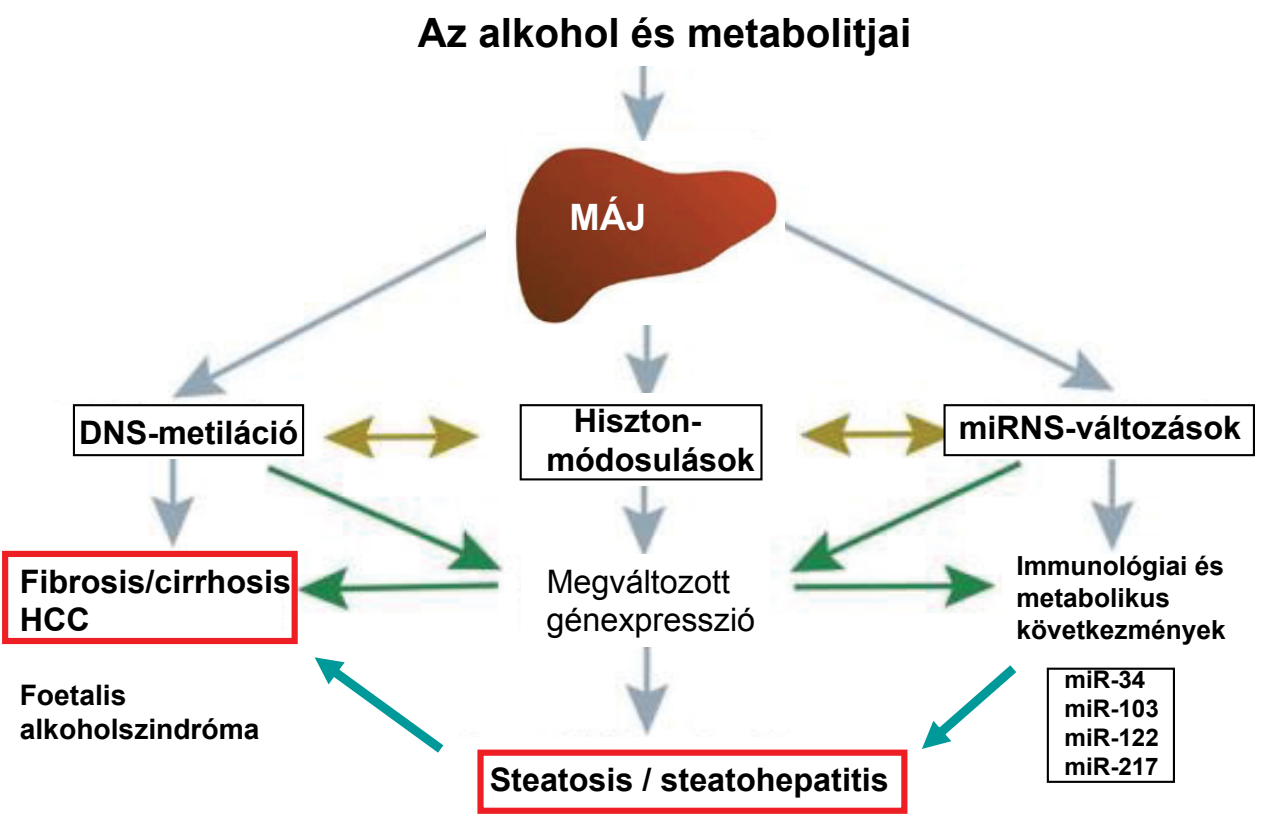

4. ábra

$$
\mid \begin{aligned}
& \text { Az alkohol epigenetikai hatásai }[30] \\
& \text { DNS = dezoxiribonuklinsav; HCC = hepatocellularis carcinoma; miRNS = mikro-RNS }
\end{aligned}
$$

Alkoholos steatosisban nő a hiszton-acetiltranszferáz aktivitása [30-33]. Ugyanakkor az alkohol csökkenti a protein-arginin-metiltranszferáz-l (PRMTl) aktivitását, csökken a hiszton-arginin metilációja, csökken a hepatocytanukleárisfaktor-4- $\alpha$ (Hnf4 $\alpha)$ expressziója, ami fokozott sejtproliferációhoz, karcinogenezishez vezet [34].

Az alkohol okozta hisztonmodifikáció szerepet kap a gyulladásos válaszban, az endotoxinhatás fokozásában. De megváltozhat az $A L D H-t$ kódoló gének, valamint a c-jun onkogén és a plazminogénaktivátorinhibitor-1 (PAIl)-gén kifejeződése is, és mindez hat a fibrogenezisre és a tumorgenezisre. Alkoholexpozícióra a PNPLA3gén regulátor régiójában bekövetkező hipermetiláció is fokozza a fibrogenezist [30].

A DNS-metiláció változásai is jelentősek a karcinogenezisben. Az alkohol okozta csökkent DNS-metiltranszferáz-aktivitás és csökkent DNS-metiláció módosítja az $\mathrm{ADH}$-t szabályozó gének transzkripcióját, megváltoztatja a fibrosist kontrolláló gének expresszióját, nő a HCC kockázata [32]. A hipermetilált tumorszuppresszor gének epigenetikus elcsendesítése és hipometiláció révén az onkogének aktiválása összefüggött a túléléssel alkoholos cirrhosisban és HCC-ben szenvedőkben [30, 33].

A mikro-RNS-ek (miR) génregulátor funkciót kifejtő, nem kódoló rövid RNS-molekulák, amelyek a génexpressziót transzkripciós, illetve poszttranszlációs szinten szabályozzák, célponttól függóen aktiválnak vagy szupprimálnak géneket [30, 31].

Az alkohol hatására megnő a miR-34, miR-103, miR122 expressziója; a változások érintik a lipid- és a glükózmetabolizmust, és módosíthatják a DNS-metilációs mintát is. Állatmodellben a miR-2l kifejeződése fokozódik májreszekcióra, parciális hepatectomiára, arra utalva, hogy szerepe van a regenerációs folyamatban. Az alkohol, bár fokozza a miR-2l expresszióját, hatására mégis gátolt a regeneráció. Az etanol által indukált megnövekedett miR-217-expresszió steatosist okoz [33].

$\mathrm{Az}$ alkohol okozta epigenetikai hatások nemcsak a májbetegség, hanem a foetalis alkoholszindróma kialakulásában is kulcsszerepet játszanak. Az anya nagy dózisú krónikus alkoholfogyasztása a magzatban súlyos idegfejlódési zavarhoz, neurokognitív károsodáshoz vezet, ami felnőttkorban metabolikus és immundiszfunkciókkal, kóros stresszválasszal társulhat. Állatmodellben gesztáció alatti etanolexpozícióra DNS-hidroximetilációt, kromatinelváltozásokat, bizonyos agyi régiókban, például a hippocampusban a neuralis progenitor össejtekben a DNS-metiláció csökkenését, az epigenom újraprogramozását mutatták ki [35]. A DNS-metiláció a jövőben potenciális biomarker lehet foetalis alkoholszindrómában az alkoholfogyasztás vizsgálatára $[30,35]$.

Összegezve, az alkohol okozta epigenetikai módosulások tipustól és idōtartamtól függöen negatí vagy pozitín hatásssal lehetnek a génfunkciókra. Az epigenetikai utak egymással kapcsolódva komplex regulációs hálózatot alkotnak, amelynek szisztémás hatásai lehetnek, más szervek funkcióit is érintve [30-33].

\section{Az alkoholos májbetegség egyéb kockázati tényezői}

- A nôk alkoholtoxicitásra való érzékenysége háromszor nagyobb, mint a férfiaké. Ez egyrészt hormonális (ösztrogén)hatással: fokozott bélpermeabilitással és gyulladásos válasszal, másrészt a csökkent gyomorADH-aktivitás okozta nagyobb mennyiségú alkohol 
felszívódásával, továbbá a nagyobb testzsírtömeg és kisebb víztér miatti magasabb szöveti alkoholkoncentrációval magyarázható $[4,5,36]$. Korábbi vizsgálatainkban alkoholos cirrhosisos nőbetegeink átlagéletkora 42 év volt - a férfiak több mint 10 évvel idősebbek voltak -, és nőkben a cirrhosis rövidebb idejü alkoholexpozíció után alakult ki, kisebb átlagos alkoholfogyasztás mellett [37].

- Az alkohol toxicitása dózisdependens. Az alsó határt illetően megoszlanak a vélemények. Egy metaanalízis szerint akár már 12-24 g/nap alkohol is ártalmas lehet [38], de általában az az elfogadott, hogy 40-60 g/nap alkoholfogyasztás esetén kell jelentős májkárosodással számolni [5-7]. A különböző ivásminták szerepe is ellentmondásos: nem eldöntött, hogy a rendszeres napi ivás vagy az epizodikus „nagy ivászatok” (binge drinking) esetén nagyobb-e a károsító hatás. Askgaard és mtsai szerint az előbbi jelenti a nagyobb kockázatot a cirrhosis kialakulására [39], míg Åberg és mtsai azt mutatták ki, hogy a „rohamivás” az ártalmasabb, függetlenül az átlagban elfogyasztott alkohol mennyiségétől [40].

- A táplálkozással kapcsolatban az alkoholistákban gyakran került előtérbe a D-vitamin-hiány jelentősége, mind alkoholos, mind nem alkoholos zsírmájbetegségben (NAFLD) [41].

- Obesitasban a lipotoxicitás szinergista az alkohol toxicitásával: az oxidatív stressz, a gyulladás, az immundiszfunkció következtében az elhízott nagyivókban kétszeres a cirrhosisincidencia [42]. Kontrollálatlan diabetesben is hasonló hatással lehet számolni (HR: 3,6) [43].

- A dohányzást illetően azt közölték, hogy napi egy doboz cigaretta a háromszorosára növeli a HCC és a tüdőrák kockázatát alkoholistákban a nem dohányzókhoz képest [44].

- A kávéfogyasztás pozitív hatása egyre inkább elfogadott: napi 4 csésze kávé 38\%-kal csökkenti a cirrhosiskockázatot (RR: 0,62) [45].

- A virushepatitis (HBV, HCV) gyorsítja a progressziót alkoholos májbetegségben, míg a napi $50 \mathrm{~g}$ alkoholfogyasztás HCV-fertőzésben súlyosbítja a fibrosist [46]. (Minden vírushepatitisben absztinencia ajánlott.) Alkoholistákban 3-30-szor gyakoribb a HCVinfekció előfordulása [47].

\section{Az alkoholos májbetegség reverzibilitása és az absztinencia}

A krónikus gyulladásos májbetegségek közös vonása a necroinflammatio által kiváltott fibrogenezis, amely a progresszió alapja. A kórok eliminálása a fibrosis regreszsziójához, míg az inzultus tartós fennállása cirrhosishoz, májelégtelenséghez vezet. Fontos tehát az elinditó tényezô kiküszöbölése. Ezt igazolták nemcsak a hepatitisvírusfertőzések antivirális szerekkel történő eradikálása során, de alkoholos kórképekben is erre utaltak azok a vizsgála- tok, amelyekben az absztinencia hatására a máj szövettani változásait, illetve az absztinensek és a továbbivók túlélését elemezték. A legújabb hazai irodalomban Hagymási Krisztina dolgozata is részletesen foglalkozik e kérdéskörrel [9].

Alkoholos steatohepatitisben absztinenciára kórszövettanilag igazolható volt 4-6 héten belül a steatosis és a gyulladás megszünése, majd a ballonképződés, és később a pericellularis fibrosis eltünése. Ugyanakkor cirrhosisban 6 hónap absztinencia után macronodulusképződés által a kötőszöveti sövények fragmentálódását, és a hisztológiai kép javulását ( „remodeling”) is kimutatták, bár a cirrhosis regresszióját vitatták [48].

$\mathrm{Az}$ alkoholos májbetegség kórlefolyásában az alkoholmegvonás hatását 40 évvel ezelőtt Powell és Klatskin elsőként demonstrálta 1951 és 1963 között észlelt 278, hisztológiailag igazolt Laennec-cirrhosisos betegben [49]. A neves szerzőpáros vizsgálatában 185 továbbivó és 93 absztinens esetében az 5 éves túlélés 63,0\% volt az absztinensekben és $40,5 \%$ a továbbivókban. A túlélésben szignifikáns különbség először a 3. év végén jelentkezett. A diagnózis idején 233 beteg szenvedett dekompenzált és 45 kompenzált („korai”) cirrhosisban. Öt év után a dekompenzált absztinenesek 60\%-a, a továbbivók 34\%-a, míg a kompenzált absztinensek $88,9 \%$-a, a továbbivók 68,2\%-a élt. A szerzők - mivel a cirrhosis csak a nagyivók kis részében fejlődik ki - a „gazdai tényezők” (akkor még nem ismert) szerepét feltételezték.

Verrill és mtsai [50] 1995 és 2000 között követett 84 cirrhosisos betegben a diagnózistól számított 30 nap után állapították meg az absztinencia meglétét vagy a továbbivást. (Ezt az időtartamot tekintették a hosszú távú ivási magatartás prediktorának, amit késóbbi utánvizsgálatuk 98\%-ban megerősített.) Átlag 7 év után az absztinensek $72 \%$-a, a továbbivók 44\%-a élt. (Az 5 éves túlélés 75\% versus $50 \%$ volt - 10\%-kal nagyobb, mint Powell és Klatskin idején.) Következtetésük: a korán elkezdett absztinenciával még cirrhosisban is megelőzhető a progresszió, valamint a májtranszplantáció szükségessége.

Marot és mtsai [51] 21 éves periódus alatt (átlag 58 hónapos követési idővel) 529 alkoholos, 145 hepatitis Cvírus (HCV-) és 78 nem alkoholos zsírmáj (NAFLD-) eredetű cirrhosisos betegben hasonlították össze a kórlefolyást. Az alkoholos cirrhosisos betegek átlag 10 évvel fiatalabbak voltak, mint a másik két csoport betegei (56 versus 67 , illetve 63 év), és elórehaladottabb volt a betegségük (Child B/C cirrhosis $48 \%$ versus $8 \%$ és $17 \%$ ). A 10 éves, májeredetű halálozás az alkoholos csoportban $42 \%$, HCV-ben 29,6\% és NAFLD-ben 26,8\% volt. Alkoholos cirrhosisban az absztinens betegekben a 10 éves kumulatív mortalitás $42,4 \%$, a továbbivókban $63 \%$ volt. (A halálozás az absztinensekben hasonló volt, mint HCV- és NAFLD-cirrhosisban $[42,4 \%, 47,7 \%, 49,9 \%])$. HCVcirrhosisban a tartós virológiai válasz a 10 éves mortalitást 42\%-ról 14\%-ra (HR: 0,47) csökkentette. A szerzők adatai szerint az alkoholos cirrhosis súlyosabb, rosszabb prognózisú, mint a $\mathrm{HCV}$ - vagy a NAFLD-eredetű. Az 
absztinencia javította a túlélést, ha nem is olyan mértékben, mint HCV-ben a víruseradikáció.

Lackner és mtsai [52] 60 kompenzált („korai”) és 132 dekompenzált alkoholos cirrhosisos beteget átlag 4 éven át követtek. Az absztinencia aránya a két csoportban hasonló volt $(30 \%$, illetve $32 \%)$. Az 5 éves túlélés $87 \%$ volt a „korai" stádium esetén, illetve 57\% dekompenzált cirrhosisban. A 10 éves túlélés F0-F2 fibrosisú betegekben 100\%, F3/F4 stádiumban 54\% volt. Dekompenzált cirrhosisban a nők 10 éves túlélése alacsonyabb volt, mint a férfiaké ( $28 \%$ versus $50 \%$ ). A kompenzált betegek absztinenciája esetén a 10 éves túlélés $95 \%$, a továbbivókban $70 \%$ ( $\mathrm{p}<0,017)$, dekompenzált cirrhosis esetén absztinensekben 65\%, továbbivókban $37 \%(\mathrm{p}<0,013)$ volt. (Négy évtizeddel korábban, az 5 éves túlélés volt ilyen arányú.) A szerzők fontosnak tartották alkoholos májbetegségben is a fibrosisdiagnosztikát és az absztinencia korai bevezetését.

Összegezve, az alkoholos májbetegség reverzibilitására utal, hogy az absztinencia nemcsak a steatohepatitis és a fibrosis regressziójáboz vezethet, de a cirrhosis kompenzácioját és a továbbivókkal szemben az élettartam megnövekedését is okozhatja.

Az absztinencia elérésében és fenntartásában alapvető fontosságú a farmakonoknak (naltrexon, nalmefen, baklofen) és a pszichológiai módszereknek (például kognitív magatartásterápia) a kombinálása, az önsegítő csoportokban (például Anonim Alkoholisták, AA) való részvétel, továbbá az addiktológus, a pszichológus, a pszichiáter, a hepatológus és a családorvos szoros együttmúködése.

A betegben tudatosítani kell az alkohol okozta károsodás kockázatát. Az úgynevezett rövid intervenció '5 $A$ ' modellje szerint a teendő: Ask: kérdezni a használatról; Advice: tanácsolni a leszokást; Assist: segíteni; Assess: értékelni a hozzáállást; Arrange: intézkedni, és folyamatosan követni a kórlefolyást [53]. Mindez pedig sokkal több, mint egyszerüen azt mondani: „Nem szabad inni, mert..." Ha pedig a terápiás eljárások sikeresek, a prognózis megváltoztatható. Az alkoholos cirrhosist megelőzhető betegségnek kell tekinteni [4-7, 10].

\section{Következtetés}

A jövőben a genetikai tényezők ismerete segíthet alkoholos májbetegségben a nagy kockázatú csoportok azonosításában, HCC irányában az optimális szűrési intervallum kidolgozásásban, a transzplantációval kapcsolatos döntésben (prioritás), alkoholos hepatitis esetén a szteroidra nem reagálók közül a korai transzplantációra szorulók szelekciójában. A génpolimorfizmusok és az epigenetikai markerek alapján azonosíthatók lehetnek azok az alkoholfogyasztók, akik számára különösen fontos a prevenció, a terápia és a hepatológiai követés. Az alkoholos májbetegség megelőzhető, progressziója gátolható, ehhez azonban az absztinencia mielőbbi elérése és fenntartása szükséges, ami komplex, multidiszciplináris feladat.
Anyagi támogatás: A közlemény megírása anyagi támogatásban nem részesült.

Szerzői munkamegoszlás: A dolgozat a két szerző közös munkája. A cikk végleges változatát mindkét szerző elolvasta és jóváhagyta.

Érdekeltségek: A szerzőknek nincsenek érdekeltségeik.

\section{Irodalom}

[1] Pár A, Pár G. Advances in the pathogenesis of non alcoholic fatty liver disease. [Újabb adatok a nem alkoholos zsírmáj patogeneziséhez.] Orv Hetil. 2017; 158: 882-894. [Hungarian]

[2] Nádasdi Á, Somogyi A, Igaz P, et al. Non-alcoholic fatty liver disease - a summary and update based on the EASL-EASDEASO Clinical Practice Guidelines of 2016. [Nem alkoholos zsírmájbetegség - a 2016. évi közös EASL-EASD-EASO klinikai ajánlás fényében.] Orv Hetil. 2018; 159: 1815-1830. [Hungarian]

[3] World Health Organization. Global status report on noncommunicable diseases 2014. WHO Library Cataloguing-in-Publication Data, Geneva, 2014.

[4] Farooq MO, Bataller R. Pathogenesis and management of alcoholic liver disease. Dig Dis. 2016; 34: 347-355.

[5] Stickel F, Datz C, Hampe J, et al. Pathophysiology and management of alcoholic liver disease: update 2016. Gut Liver 2017; 11 : 173-188.

[6] European Association for the Study of the Liver. EASL Clinical Practice Guidelines: management of alcohol-related liver disease. J Hepatol. 2018; 69: 154-181.

[7] Singal AK, Bataller R, Ahn J. AGC Clinical Guideline: alcoholic liver disease. Am J Gastroenterol. 2018; 113: 175-194.

[8] Pár A, Pár G. Alcoholic liver disease - 2018: pathogenesis, diagnosis, treatment. [Alkoholos májbetegség - 2018: patogenezis, diagnózis, kezelés.] Orvostovábbk Szle 2018; 25: 17-28. [Hungarian]

[9] Hagymási K. Can improve the condition of patient with alcoholic liver disease after abstinence? [Javulhat-e az alkoholos májbeteg állapota az absztinenciát követően?] Orvostovábbk Szle 2018; 25: 29-31. [Hungarian]

[10] Stickel F, Moreno C, Hampe J, et al. The genetics of alcohol dependence and alcohol-related liver disease. J Hepatol. 2017; 66: 195-211.

[11] Buch S, Stickel F, Trépo E, et al. A genome-wide association study confirms PNPLA3 and identifies TM6SF2 and MBOAT7 as risk loci for alcohol-related cirrhosis. Nat Genet. 2015; 47 : 1443-1448.

[12] Anstee QM, Seth D, Day CP. Genetic factors that affect risk of alcoholic and nonalcoholic fatty liver disease. Gastroenterology 2016; 150: 1728-1744.e7.

[13] Scott E, Anstee QM. Genetics of alcoholic liver disease and nonalcoholic steato-hepatitis. Clin Med. 2018; 18(Suppl 2): S54S59.

[14] Hrubec Z, Omenn GS. Evidence of genetic predisposition to alcoholic cirrhosis and psychosis: twin concordances for alcoholism and its biological end points by zygosity among male veterans. Alcohol Clin Exp Res. 1981; 5: 207-215.

[15] Levy RE, Catana AM, Durbin-Johnson B, et al. Ethnic differences in presentation and severity of alcoholic liver disease. Alcohol Clin Exp Res. 2015; 39: 566-574.

[16] Anstee QM, Daly AK, Day CP. Genetics of alcoholic liver disease. Semin Liver Dis. 2015; 35: 361-374.

[17] Marshall AW, Kingstone D, Boss M, et al. Ethanol elimination in males and females: relationship to menstrual cycle and body composition. Hepatology 1983; 3: 701-706. 
[18] Li D, Zhao H, Gelernter J. Strong association of the alcohol dehydrogenase $1 \mathrm{~B}$ gene (ADHIB) with alcohol dependence and alcohol-induced medical diseases. Biol Psychiatry 2011; 70: 504-512.

[19] Li D, Zhao H, Gelernter J. Strong protective effect of the aldehyde dehydrogenase gene (ALDH2) 504lys (*2) allele against alcoholism and alcohol induced medical diseases in Asians. Hum Genet. 2012; 131: 725-737.

[20] Marcos M, Gomez-Munuera M, Pastor I, et al. Tumor necrosis factor polymorphisms and alcoholic liver disease: a HuGE review and meta-analysis. Am J Epidemiol. 2009; 170: 948-956.

[21] Romeo S, Kozlitina J, Xing C, et al. Genetic variation in PNPLA3 confers susceptibility to nonalcoholic fatty liver disease. Nat Genet. 2008 ; 40: 1461-1465.

[22] Stickel F, Buch S, Lau K, et al. Genetic variation in the PNPLA3 gene is associated with alcoholic liver injury in caucasians. Hepatology 2011; 53: 86-95.

[23] Trépo E, Nahon P, Bontempi G, et al. Association between the PNPLA3 (rs738409 C>G) variant and hepatocellular carcinoma: evidence from a meta-analysis of individual participant data. Hepatology 2014; 59: 2170-2177.

[24] Salameh H, Raff E, Erwin A, et al. PNPLA3 gene polymorphism is associated with predisposition to and severity of alcoholic liver disease. Am J Gastroenterol. 2015; 110: 846-856.

[25] Falleti E, Cussigh A, Cmet S, et al. PNPLA3 rs738409 and TM6SF2 rs58542926 variants increase the risk of hepatocellular carcinoma in alcoholic cirrhosis. Dig Liver Dis. 2016; 48: 69-75.

[26] Atkinson SR, Way MJ, McQuillin A, et al. Homozygosity for rs738409:G in PNPLA3 is associated with increased mortality following an episode of severe alcoholic hepatitis. J Hepatol. 2017; 67: 120-127.

[27] Kozlitina J, Smagris E, Stender S, et al. Exome-wide association study identifies a TM6SF2 variant that confers susceptibility to nonalcoholic fatty liver disease. Nat Genet. 2014; 46: 352-356.

[28] Way MJ, Atkinson S, McQuillin A, et al. A functional variant in TM6SF2 associates with alcohol-related cirrhosis risk in a British and Irish population. J Hepatol. 2015; 62(Suppl 2): S772.

[29] Mancina RM, Dongiovanni P, Petta S, et al. The MBOAT7TMC4 variant rs641738 increases risk on nonalcoholic fatty liver disease in individuals of European descent. Gastroenterology 2016; 150: 1219-1230.e6.

[30] Shukla SD, Lim RW. Epigenetic effects of ethanol on the liver and gastrointestinal system. Alcohol Res. 2013; 35: 47-55.

[31] Dippold RP, Vadigepalli R, Gonye GE, et al. Chronic ethanol feeding alters miRNA expression dymanics during liver regeneration. Alcohol Clin Exp Res. 2013; 37(Suppl 1): E59-E69.

[32] Villanueva A, Portela A, Sayols S, et al. DNA methylation-based prognosis and epidrivers in hepatocellular carcinoma. Hepatology $2015 ; 61$ : 1945-1956.

[33] Zakhari S. Alcohol metabolism and epigenetics changes. Alcohol Res. 2013; 35: 6-16.

[34] Zhao J, Adams A, Roberts B, et al. Protein arginine methyltransferase 1 - and Jumonji $\mathrm{C}$ domain-containing protein 6-dependent arginine methylation regulate hepatocyte nuclear factor 4 alpha expression and hepatocyte proliferation in mice. Hepatology 2018; 67: 1109-1126.

[35] Lussier AA, Weinberg J, Kober MS. Epigenetics studies of fetal alcohol spectrum disorder: where are we now? Epigenomics 2017; 9: 291-311.

[36] Rehm J, Baliunas D, Borges GL, et al. The relation between different dimensions of alcohol consumption and burden of disease. An overview. Addiction 2010; 105: 817-843.
[37] Pár A. Prognosis of alcoholic liver disease. Clinical experiences. [Az alkoholos májbetegség prognózisa. Klinikai tapasztalataink.] Orvosképzés 1987; 62: 169-175. [Hungarian]

[38] Rehm J, Taylor B, Mohapatra S, et al. Alcohol as a risk factor for liver cirrhosis: a systematic review and meta-analysis. Drug Alcohol Rev. 2010; 29: 437-445.

[39] Askgaard G, Grønbaek M, Kjaer MS, et al. Alcohol drinking pattern and risk of alcoholic liver cirrhosis: a prospective cohort study. J Hepatol. 2015; 62: 1061-1067.

[40] Åberg F, Helenius-Hietala J, Puukka P, et al. Binge drinking and the risk of liver events: a population-based cohort study. Liver Int. 2017; 37: 1373-1381

[41] Trépo E, Ouziel R, Pradat P, et al. Marked 25-hydroxyvitamin D deficiency is associated with poor prognosis in patients with alcoholic liver disease. J Hepatol. 2013; 59: 344-350.

[42] Hart CL, Morrison DS, Batty GD, et al. Effect of body mass index and alcohol consumption on liver disease: analysis of data from two prospective cohort studies. BMJ 2010; 340: cl240.

[43] Åberg F, Helenius-Hietala J, Puukka P, et al. Interaction between alcohol consumption and metabolic syndrome in predicting severe liver disease in the general population. Hepatology 2018; 67: 2141-2149.

[44] Dam MK, Flensborg-Madsen T, Eliasen M, et al. Smoking and risk of liver cirrhosis: a population-based cohort study. Scand J Gastroenterol. 2013; 48: 585-591.

[45] Kennedy OJ, Roderick P, Buchanan R, et al. Systematic review with meta-analysis: coffee consumption and the risk of cirrhosis. Aliment Pharmacol Ther. 2016; 43: 562-574.

[46] Monto A, Patel K, Bostrom A, et al. Risks of a range of alcohol intake on hepatitis C-related fibrosis. Hepatology 2004; 39: 826-834.

[47] Punzalan CS, Bukong TN, Szabo G. Alcoholic hepatitis and $\mathrm{HCV}$ interactions in the modulation of liver disease. J Viral Hepat. 2015; 22: 769-776.

[48] Theise ND. Histopathology of alcoholic liver disease. Clin Liver Dis. 2013; 2: 64-67.

[49] Powell WJ Jr, Klatskin G. Duration of survival in patients with Laennec's cirrhosis. Influence of alcohol withdrawal, and possible effects of recent changes in general management of the disease. Am J Med. 1968; 44: 406-420.

[50] Verrill C, Markham H, Templeton A, et al. Alcohol-related cirrhosis - early abstinence is a key factor in prognosis, even in the most severe cases. Addiction 2009; 104: 768-774.

[51] Marot A, Henrion J, Knebel JF, et al. Alcoholic liver disease confers a worse prognosis than HCV infection and non-alcoholic fatty liver disease among patients with cirrhosis: an observational study. PLoS ONE 2017; 12: e0186715.

[52] Lackner C, Spindelboeck W, Haybaeck J, et al. Histological parameters and alcohol abstinence determine long-term prognosis in patients with alcoholic liver disease. J Hepatol. 2017; 66: 610-618.

[53] AHRQ. Five major steps to intervention (the " 5 A's"). Available from: https://www.ahrq.gov/professionals/clinicians-providers/guidelinesrecommendations/tobacco/5steps.html Page last reviewed July 2018 [accessed: November 7, 2018].

(Pár Alajos dr., Pécs, Ifjúság u. 13., 7624 e-mail: par.alajos@pte.hu)

A cikk a Creative Commons Attribution 4.0 International License (https://creativecommons.org/licenses/by/4.0/) feltételei szerint publikált Open Access közlemény, melynek szellemében a cikk bármilyen médiumban szabadon felhasználható, megosztható és újraközölhetö, feltéve, hogy az eredeti szerző és a közlés helye, illetve a CC License linkje és az esetlegesen végrehajtott módosítások feltüntetésre kerülnek. (SID_1) 